\title{
Seedling regeneration on decayed pine logs after the deforestation events caused by pine wilt disease
}

\section{Y. Fukasawa}

Fukasawa Y., 2016. Seedling regeneration on decayed pine logs after the deforestation events caused by pine wilt disease. Ann. For. Res. 59(1): 191-198.

Abstract. Coarse woody debris (CWD) forms an important habitat suitable for tree seedling establishment, and the CWD decay process influences tree seedling community. In Japan, a severe dieback of Pinus densiflora Sieb. \& Zucc. caused by pine wilt disease (PWD) damaged huge areas of pine stands but creates huge mass of pine CWD. It is important to know the factors influencing seedling colonization on pine CWD and their variations among geographical gradient in Japan to expect forest regeneration in post-PWD stands. I conducted field surveys on the effects of latitude, climates, light condition, decay type of pine logs, and log diameter on tree seedling colonization at ten geographically distinct sites in Japan. In total, 59 tree taxa were recorded as seedlings on pine logs. Among them, 13 species were recorded from more than five sites as adult trees or seedlings and were used for the analyses. A generalized linear model showed that seedling colonization of Pinus densiflora was negatively associated with brown rot in sapwood, while that of Rhus trichocarpa was positively associated with brown rot in heartwood. Regeneration of Ilex macropoda had no relationships with wood decay type but negatively associated with latitude and MAT, while positively with log diameter. These results suggested that wood decay type is a strong determinant of seedling establishment for certain tree species, even at a wide geographical scale; however, the effect is tree species specific.

Keywords brown rot, dead wood, pine wilt disease, Pinus densiflora, seedling colonization

Author. Yu Fukasawa (fukasawayuu@gmail.com) - Laboratory of Forest Ecology, Graduate School of Agricultural Science, Tohoku University, Naruko-onsen, Osaki, Miyagi 989-6711, Japan. Tel: +81 22984 7397, Fax: +81 22984 6490.

Manuscript received October 10, 2015; revised March 22, 2016; accepted April 02, 2016; online first April 08, 2016.

\section{Introduction}

Coarse woody debris (CWD) forms a suitable microsite for tree seedling establishment in various forest ecosystems, from boreal and subalpine, temperate to tropical areas (Harmon et al. 1986, Lonsdale et al. 2008, Sanchez et al. 2009, Fukasawa 2012, Bače et al. 2012). To reveal the factors affecting seedling colonization on CWD is essential to understand forest 
dynamics.

The relative importance of the factors affecting seedling regeneration changes along a spatial scale. Münzbergová (2004) reported that microsite factors such as substrate conditions become less important with increasing spatial scale from local to regional where the climatic filtering becomes critical (Swenson et al. 2012). On the other hand, organisms colonizing CWD are strongly affected by microsite factors, i.e., tree species, decay stage, and physicochemical properties of CWD, even at a large geographical scale (Heilmann-Clausen et al. 2014). Among CWD properties, it has recently been revealed that the wood decay type of CWD strongly affects seedling colonization (Bače et al. 2012, Fukasawa 2012). The decay type is the traditional classification of decayed wood based on physicochemical properties, and differences are caused by lignocellulose-decomposition capabilities of various fungal species (Eaton \& Hale 1993); white, brown, and soft rots are generally recognized. Bače et al. (2012) reported that low $\mathrm{pH}$ and fragile substrate of brown rotted logs prevented seedling regeneration of Picea abies. On the other hand, the low $\mathrm{pH}$ condition of brown rotted logs may be favored by seedlings of an Ericales tree Clethra barbinervis (Fukasawa 2012). These contrasting results seemed to suggest that the effect of decay type on seedling colonization is tree-species specific. However, this effect had been tested for only a couple of tree species at single site for each, and thus the generality of this effect is poorly explored. Furthermore, the relative importance of wood decay type compared to climatic and forest vegetation factors at larger spatial scales have not yet been tested.

In Japan, a severe dieback of Pinus densiflora Sieb. \& Zucc. caused by pine wilt disease (PWD) started from the 1970s and continues to date. Consequently, large masses of dead $P$. densiflora logs have accumulated on the forest floor across Japan (Kato \& Hayashi 2006), which have become regeneration sites for tree seedlings (Fukasawa 2012). P. densiflora is a 192 pioneer species, and the preference of successional tree seedlings for decayed pine logs may affect forest succession and future vegetation. In addition, a wide distribution of $P$. densiflo$r a$ allows CWD of this species to be a good material for testing the relative importance of climate, vegetation and wood decay type on seedling development along latitudinal gradient in Japan.

In order to evaluate log properties, including wood decay type, influencing seedling regeneration in post-PWD forests in a wide geographical scale, I conducted field survey at 10 sites along latitudinal gradient in Japan. The hypothesis is that wood decay type of the logs has substantial effects on seedling colonization even in a wide geographical scale.

\section{Materials and methods}

\section{Study sites}

A total of ten forest sites were selected along a latitudinal gradient in Japan (Figure 1, Table 1). The two most distant sites (KWT and TAN) were separated by approximately 1,100 $\mathrm{km}$. The vegetation currently at the sites are mixed stands of $P$. densiflora and broad-leaves, except for KGM which is a plantation of commercially grown timber (Chamaecyparis obtu$s a)$. Basal area of tree species recorded at each site was shown in Table A1. Most of the sites experienced PWD during the last few decades and underwent CWD management at some stage to prevent the spread of PWD (cutting down of infected trees, fumigation or spraying of pesticides). Data of the presence/absence of PWD, cut down, and pesticide treatment are based on interviews with the foresters and/or the field evidences (cut log piles covered with nylon sheets for pesticide fumigation treatment) on each site.

\section{Field work}

The occurrences and species of tree seedlings 


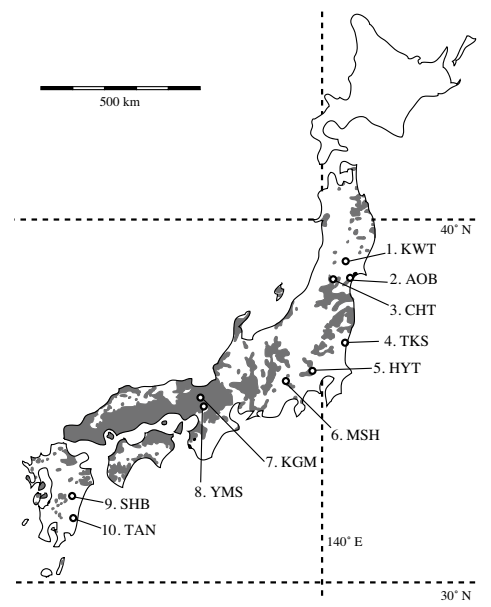

Figure 1 The natural distribution of Pinus densiflora in Japan (shaded areas, from Japan Integrated Biodiversity Information System: http://www.biodic.go.jp/kiso/fnd_f. html) and the locations of the ten study sites investigated in the present study. The abbreviations of the study sites are shown in Table 1. (height $<50 \mathrm{~cm}$ without reference to age; Streng et al. 1989) growing on decay class (DC) IV pine logs (diameter $>10 \mathrm{~cm}$ ) were recorded (26-86 logs per site) because a previous study demonstrated that seedlings were most dominant during this DC in five-decay class system (Fukasawa 2012). Wood within DC IV is considerably decayed and penetrable with a knife to approximately $5-10 \mathrm{~cm}$. At this stage, the original log circumference begins to disintegrate. Logs were randomly selected within an approximately 1 ha tract in each site. To eliminate within-stem variation in DC (Pyle \& Brown 1999), a stem section was selected for each log (ca. $2 \mathrm{~m}$ along the stem) where decay stage is uniform. Seedling frequency was calculated for each species as the percentage of the logs where the seedlings of each species occurred, regardless of the number of seedlings observed.

The decay types in the sapwood of the logs were recorded. The surface of the wood was removed using a hand axe, and presence or absence of certain decay types were recorded as

Table 1 Localities, climates, occurrences of pine wilt disease (PWD), coarse woody debris (CWD) management, pesticide usage to control PWD, and number of Pinus densiflora logs investigated in the ten sites

\begin{tabular}{llllllllllll}
\hline \multicolumn{1}{l}{ Site } & Code & $\begin{array}{l}\text { Lat. } \\
(\mathrm{N})\end{array}$ & $\begin{array}{l}\text { Long. } \\
(\mathrm{E})\end{array}$ & $\begin{array}{l}\text { Alt. } \\
(\mathrm{m})\end{array}$ & MAT & AP & PWD $\begin{array}{l}\text { Cut } \\
\text { down }\end{array}$ & $\begin{array}{l}\text { Pesti- } \\
\text { cide }\end{array}$ & $\begin{array}{l}\text { No. } \\
\text { of } \\
\operatorname{logs}\end{array}$ \\
\hline 1 Kawatabi & KWT & 38.46 & 140.45 & 547 & 8.2 & 1656.6 & No & No & No & 46 \\
2 Aobayama & AOB & 38.15 & 140.50 & 137 & 12.1 & 1291.3 & Yes & No & No & 50 \\
3 Chitoseyama & CHT & 38.14 & 140.21 & 245 & 11.5 & 1237.6 & Yes & Yes & Yes & 50 \\
4 Takasuzuyama & TKS & 36.36 & 140.38 & 178 & 13.6 & 1528.5 & Yes & No & No & 50 \\
5 Higashiyamato & HYT & 35.45 & 139.26 & 120 & 14.8 & 1560.7 & Yes & Yes & No & 79 \\
6 Masuho & MSH & 35.33 & 138.26 & 350 & 14.6 & 1167.1 & Yes & Yes & Yes & 50 \\
7 Kamigamo & KGM & 35.04 & 135.45 & 175 & 15.4 & 1442.4 & Yes & Yes & Yes & 86 \\
8 Yamashiro & YMS & 34.47 & 135.50 & 255 & 15.5 & 1388.0 & Yes & No & No & 28 \\
9 Shiiba & SHB & 32.22 & 131.10 & 1113 & 10.1 & 2750.0 & No & No & No & 50 \\
10 & Tano & TAN & 31.51 & 131.18 & 170 & 16.9 & 2515.1 & Yes & No & No & 50 \\
\hline
\end{tabular}

Note. Abbreviations: MAT (mean annual temperature) and AP (annual precipitation) data (average during 2001-2010) were obtained from the nearest weather station of each site and calibrated according to elevation difference between nearest weather station and the study site $\left(0.6^{\circ} \mathrm{C}\right.$ decrease per $100 \mathrm{~m}$ elevation), except for SHB and YMS where weather data were obtained from literature (Enoki et al. 2013, Kominami et al. 2012). Note that data of SHB was of 2003-2011 and of YMS was of 1994-2009. 
binary data, regardless of wood mass occupied by certain decay types. In this study, decay types were classified according to the macroscopic criterion of Araya (1993) as follows: Brown rot appears reddish-brown and easily breakable into cubical fragments, white rot appears whitish and bleached (yellowish- or grayish-white) and breakable into fibrous fragments, and soft rot appears dull-grey to brown with a mud-like surface. Details for decay type occurrence have been published in another paper (Fukasawa 2015a). In short, frequency of white rot was larger in cooler sites, whereas that of brown and soft rots were larger in warmer low-latitude sites in a latitudinal gradient in Japan.

The composition of adult trees was recorded at the study sites. Three to ten $10 \times 10 \mathrm{~m}$ plots were randomly selected within each site, and the basal area $(B A)$ of adult trees (diameter at breast height $>1 \mathrm{~cm}$ ) within the plots were recorded. For YMS, SHB and TAN, $B A$ data were obtained from previous studies (Goto et al. 2003, Ishihara et al. 2011, Enoki et al. 2013).

\section{Data analyses}

The effects of environmental variables on seedling colonization on the logs were tested by a generalized linear model (GLM). Latitude, MAT, AP, BA of all trees $\left(\mathrm{BA}_{\text {all }}\right)$, diameter of the logs, and the occurrences of brown rot in sapwood and heartwood of the logs were set as fixed-effect variables for explaining seedling colonization on the logs. $\mathrm{BA}_{\text {all }}$ was selected as stand-level factors as a rough proxy for light conditions (large value means low light). There were few significant correlations among the variables (Table 2). Datasets of 13 tree species, which were recorded from more than five sites as adult trees or seedlings (Table 3), were used for the analyses. Colonization index (CI) was calculated for each of these 13 species for each site according to the following equation and was used as dependent variable in GLM analysis:

$$
C I=\ln [(S / B A+0.0001)+1]
$$

where $\mathrm{S}_{\mathrm{f}}$ - Frequency of seedlings (\%) and BA - basal area $\left(\mathrm{m}^{2}\right)$. Natural logarithm transformation of the data was applied in order to reduce data range. I added 0.0001 , which was substantially less than the minimum BA value of the 13 species, to BA in order to complete CI calculation even when BA was 0. Error structures were set as Gaussian because the dependent variables were quantitative data. GLM analysis and correlation tests were conducted using R 3.1.2 (R Development Core Team 2014).

\section{Results}

In total, 59 tree taxa were recorded as seedlings on decayed pine logs at ten sites (Table 2,

Table 2 Spearman's rank correlation coefficients between independent variables

\begin{tabular}{lllllllc}
\hline Variables & Latitude & MAT & $\mathrm{AP}$ & $\mathrm{BA}_{\text {all }}$ & Sap Brown & Heart Brown & Diameter \\
\hline Latitude & 1 & $-0.64+$ & -0.36 & -0.006 & -0.47 & -0.48 & 0.20 \\
MAT & & 1 & -0.07 & -0.13 & 0.10 & 0.53 & -0.36 \\
AP & & & 1 & 0.52 & 0.31 & -0.42 & -0.33 \\
BA $_{\text {all }}$ & & & & 1 & -0.10 & $-0.66^{*}$ & 0.03 \\
Sap Brown & & & & & 1 & 0.56 & -0.05 \\
Heart Brown & & & & & & 1 & -0.04 \\
Diameter & & & & & & & 1 \\
\hline
\end{tabular}

Note. Abbreviations: BAall - basal area of all adult trees, MAT - mean annual temperature, AP - annual precipitation, Sap Brown - brown rot in sapwood, Heart Brown - brown rot in heartwood. Significance levels: $+\mathrm{P}<0.1, * \mathrm{P}<0.05$ 
Supporting Information), and 150 tree species were recorded as adult trees (Table 1, Supporting Information). The most frequent seedling occurrence was recorded on Eurya japonica at TKS. High frequencies (over 20\%) were also recorded for Abies firma, Chamaecyparis obtusa, Clethra barbinervis, Cryptomeria japonica, Ilex crenata, Pinus densiflora, Prunus spp., and Styrax japonica. Among the trees, Acanthopanax sciadophylloides, Carpinus spp., C. barbinervis, C. japonica, E. japonica, and I. macropoda, Lyonia ovalifolia var. elliptica, P. densiflora, Prunus spp., Quercus serrata, Rhus trichocarpa, S. japonica, and Swida controversa were recorded from more than five sites and their CI values were calculated (Table 3 ). High CI values (over 10) were recorded for Carpinus spp. in AOB, C. barbinervis and $S$. japonica in TKS, E. japonica in HYT, and $C$. barbinervis in MSH. There were no significant relationships between independent variables used in GLM except for between brown rot in heartwood and $\mathrm{BA}_{\text {all }}$ (Table 2). GLM results showed that CI of I. macropoda was negatively associated with latitude and MAT, while positively with log diameter (Table 4). CI of $P$. densiflora was negatively associated with brown rot in sapwood, while CI of $R$. trichocarpa was positively associated with brown rot in heartwood. CI of other 10 tree species had no association with tested variables.

\section{Discussion}

The present study clearly showed that dead pine logs in post-PWD stands have a potential role as seedbed for many tree species. Previous studies reported that decayed logs were important seedbeds for tree species especially for small-seeded taxon (Lusk 1995; Fukasawa 2012) because thick litter layer, impediments to colonization of small-seeded trees, are reduced on logs (Duchesneau \& Morin 1999; Kanno \& Seiwa 2004; Mori et al. 2004). Other factors such as shading by forest floor vegetation, soil pathogens and root competition within the soil were also reduced on CWD (Cheng \& Igarashi 1987; Harmon \& Franklin 1989; Coomes \& Grub 2000). In the present study, seedlings frequently recorded on pine logs or widely recorded more than five sites were all small-seeded species except for Qurecus serrata (dry weight: $1460 \mathrm{mg}$, Xiao et al. 2004): Abies sp. (18 mg, Nakashizuka 1989), Acanthopanax sciadophylloides (7.5 mg, Otani 2002), Carpinus spp. (3.0 mg, Hori \& Tsuge, 1993), Chamaecyparis obtusa (2.7 mg, Nakashizuka 1989), Clethra barbinervis (0.056-0.1 mg, Nakashizuka 1989; Kobayashi

Table 3 Colonization index (CI) of thirteen tree species that were recorded more than five sites as seedlings or as adult trees. Site codes similarly to Table 1 .

\begin{tabular}{lrrrrrrrrrr}
\hline Tree & KWT & AOB & CHT & TKS & HYT & MSH & KGM SHB & TAN & YMS \\
\hline Acanthopanax sciadophylloides & 0 & 0 & 7.581 & 0 & 0 & 0 & 1.048 & 0 & 0 & 0 \\
Carpinus spp. & 2.150 & 10.597 & 0 & 0 & 0.498 & 3.166 & 0 & 0 & 0 & 0 \\
Clethra barbinervis & 0 & 4.377 & 0 & 12.206 & 2.870 & 10.597 & 2.015 & 3.534 & 9.904 & 0 \\
Cryptomeria japonica & 3.850 & 9.904 & 3.519 & 1.176 & 0 & 3.495 & 0 & 0 & 0 & 0 \\
Eurya japonica & 0 & 0 & 0 & 2.358 & 10.090 & 0 & 2.055 & 0 & 3.103 & 2.118 \\
Ilex macropoda & 0 & 0.952 & 1.520 & 0 & 0.957 & 0 & 0 & 4.897 & 0 & 0 \\
Lyonia ovalifolia var. elliptica & 0 & 0 & 0 & 0 & 0 & 0 & 2.163 & 4.211 & 0 & 0 \\
Pinus densiflora & 0.406 & 0.362 & 2.121 & 0.115 & 0.121 & 11.290 & 0 & 0 & 0 & 0 \\
Prunus spp. & 0 & 1.328 & 1.749 & 0 & 0.277 & 1.752 & 0 & 0 & 0 & 0 \\
Quercus serrata & 0 & 0.920 & 0 & 3.165 & 0.123 & 0.879 & 0 & 0 & 0 & 0 \\
Rhus trichocarpa & 0 & 0 & 8.416 & 0 & 0 & 11.290 & 0 & 0 & 0 & 0 \\
Styrax japonica & 0 & 0 & 2.587 & 12.206 & 0 & 5.965 & 0 & 0 & 0 & 0 \\
Swida controversa & 0 & 0 & 0 & 0.983 & 1.560 & 7.314 & 0 & 0 & 0 & 0 \\
\hline
\end{tabular}


Table 4 Parameter estimated by GLM for the effects of variables on the colonization index $(C I)$ of thirteen tree species

\begin{tabular}{|c|c|c|c|c|c|c|c|}
\hline Tree & Latitude & MAT & $\mathrm{AP}$ & $\mathrm{BA}_{\text {all }}$ & $\begin{array}{c}\text { Sap } \\
\text { brown }\end{array}$ & $\begin{array}{l}\text { Heart } \\
\text { brown }\end{array}$ & Diameter \\
\hline $\begin{array}{l}\text { Acanthopanax } \\
\text { sciadophylloides }\end{array}$ & 0.560 & -0.017 & 0.001 & 0.010 & 0.037 & 0.088 & 0.064 \\
\hline Carpinus spp. & 1.901 & 0.390 & 0.010 & 0.077 & -0.370 & 0.347 & -0.087 \\
\hline Clethra barbinervis & 3.156 & 1.325 & 0.027 & 0.254 & -0.912 & 1.116 & -0.785 \\
\hline Cryptomeria japonica & 2.454 & 0.292 & 0.013 & 0.093 & -0.417 & 0.481 & -0.229 \\
\hline Eurya japonica & 0.288 & 1.357 & -0.005 & $-0.296+$ & 0.489 & $-0.789+$ & $0.791+$ \\
\hline Ilex macropoda & $-1.116^{*}$ & $-0.629 *$ & $-0.004+$ & -0.006 & $0.106+$ & $-0.144+$ & $0.296^{*}$ \\
\hline $\begin{array}{l}\text { Lyonia ovalifolia var. } \\
\text { elliptica }\end{array}$ & -1.776 & -0.785 & -0.008 & 0.049 & 0.132 & -0.151 & 0.171 \\
\hline Pinus densiflora & 1.133 & -0.348 & 0.016 & -0.003 & $-0.764 *$ & $0.918+$ & $-0.641+$ \\
\hline Prunus spp. & 0.487 & 0.039 & 0.003 & 0.003 & $-0.124+$ & $0.158+$ & -0.043 \\
\hline Quercus serrata & 0.106 & 0.043 & 0.0003 & 0.073 & -0.065 & 0.085 & -0.051 \\
\hline Rhus trichocarpa & 1.704 & -0.340 & 0.018 & -0.006 & $-0.756+$ & $1.019 *$ & -0.590 \\
\hline Styrax japonica & 0.415 & -0.120 & 0.004 & 0.259 & -0.390 & 0.570 & -0.422 \\
\hline Swida controversa & 0.545 & -0.078 & 0.009 & -0.036 & -0.420 & 0.453 & -0.284 \\
\hline
\end{tabular}

Note. Abbreviations: BAall - basal area of all adult trees, MAT - mean annual temperature, AP - annual precipitation, Sap Brown - brown rot in sapwood, Heart Brown - brown rot in heartwood. Statistical significance: $+P<$ $0.1, * P<0.05$.

\& Kamitani 2000), Cryptomeria japonica (1.8 mg, Ooya 2000), Eurya japonica (0.3mg, Sakai et al. 2005), Ilex spp. (7.2-7.5 mg, Otani 2002), Pinus densiflora (10.1 mg, Noguchi et al. 1991), Prunus spp. (57.0-59.9 mg, Takita et al. 1998; Otani 2002), Rhus trichocarpa (20 mg, Osada 2005), Styrax japonica (231 mg, Takita et al. 1998), Swida controversa (44.350.3 mg, Takita et al. 1998; Otani 2002).

Despite the differences in latitude, climate and $\log$ diameter, decay type of pine logs was the single significant factor affecting seedling colonization of $P$. densiflora and $R$. trichocarpa on the logs. This result supports the hypothesis that wood decay type has substantially strong effects on seedling colonization of certain tree species. The most critical factor associated with wood decay type is possibly the wood $\mathrm{pH}$, which is significantly lower in brown rot than in other decay types (Bače et al. 2012; Fukasawa 2012). Phenolic acids released from plant decomposition often reduce and even halt natural regeneration of Pinaceae tree species through inhibition of primary root growth in seedlings (Mallik 2003). Bače et al. (2012) reported that seedlings of Picea abies prefer white rotted logs than brown rotted logs. Similarly, I reported that $P$. densiflora seedlings were well established on white rotted logs (Fukasawa 2015b) consistent with the present study. On the other hand, species in Ericales were known to be adapted to acidic conditions through metabolic process evolution in their symbiotic mycorrhizal associations (Mallik 2003). Formerly, it was reported that seedling density of $C$. barbinervis (Ericales) was higher on brown rotted logs than other decay types in a stand-level study (Fukasawa 2012). In the present study, however, $C$. barbinervis had no associations with brown rotted logs as well as other Ericales species such as E. japonica and Lyonia ovalifolia var. elliptica. The reason why C. barbinervis had no associations with brown rotted logs in the present study is not clear, but 
probably interactions with other unknown regional factors may masked the relationship in such a wide scale dataset. The present study found that $R$. trichocarpa prefers brown rotted logs for their regeneration, but the reason remains unclear.

Because the decay type distribution of pine logs has a geographical gradient (Fukasawa 2015a), decay type effects on seedling colonization could affect geographical differences in forest regeneration. For example, regeneration of $P$. densiflora may be inhibited in low latitude areas where brown rot occurred more frequently than in northern areas. While seedlings stimulated by brown rot such as $R$. trichocarpa and $C$. barbinervis could be promoted in low latitude areas. However, as shown in the present study, regeneration of other tree species have no associations with log decay types or affected strongly by climatic conditions and other log factors as I. macropoda than wood decay type in this wide scale datasets. Further detailed field studies at local to regional scales and greenhouse experimental studies are required to evaluate the effects of wood decay type on seedling colonization of the other small-seeded canopy species to understand forest succession in post-PWD forests.

\section{Conclusions}

The present study demonstrates the importance of CWD as seedbeds for tree seedlings after the forest dieback events caused by pine wilt disease. Difference in wood decay type caused by inhabitant fungal community was revealed to be a strong determinant of tree seedling establishment on CWD from a dataset obtained from 10 forest sites in Japan. Depending on seedling species, both positive and negative associations were detected between brown rot of wood tissue and seedling frequency. Further researches are needed to reveal the kinetics causing such difference in response to wood decay types among seedling species.

\section{Acknowledgements}

The author is grateful for fieldwork assistance provided by Mioko Ataka, Tsutomu Enoki, Taiki Inoue, Shin-ichi Kawakami, Yuji Kominami, Katsuyoshi Kubota, Tsuyoshi Sato, Masahiro Takagi. I also thank Kenji Seiwa for valuable discussions. This study was financially supported by Japan Society for the Promotion of Science (JSPS) KAKENHI Grant Number 23780156 to Y.F.

\section{References}

Araya K., 1993. Relationship between the decay types of dead wood and occurrence of Lucanid beetles (coleoptera: lucanidae). Appl Entomol Zool 28:27-33.

Bače R., Svoboda M., Pouska V., Janda P., Červenka J., 2012. Natural regeneration in Central-European subalpine spruce forests: Which logs are suitable for seedling recruitment? For Ecol Manage 266:254-262.

Cheng D., Igarashi T., 1987. Fungi associated with natural regeneration of Picea jezoensis Carr. in seed stage. Res Bull Coll Exp For 44:175-188.

Coomes D.A., Grubb P.J., 2000. Impacts of root competition in forests and woodlands: a theoretical framework and review of experiments. Ecol Monog 70:171-207.

DOI: 10.1890/0012-9615(2000)070[0171:IORCIF]2.0. $\mathrm{CO} ; 2$

Duchesneau R., Morin H., 1999. Early seedling demography in balsam fir seedling banks. Can J For Res 29:1502-1509. DOI: 10.1139/x99-090

Eaton R.A., Hale M.D.C., 1993. Wood: decay, pests and protection. Chapman \& Hall, London, 519 p.

Enoki T., Kubota K., Kaji K., Kabemura Y., Shiiba Y., Inoue S., Utsumi Y., 2013. Monitoring plots for long-term forest dynamics in the Shiiba Research Forest. Bull Kyushu Univ For 94:40-47 (in Japanese).

Fukasawa Y., 2012. Effects of wood decomposer fungi on tree seedling establishment on coarsewoody debris. For Ecol Manage 266:232-238.

Fukasawa Y., 2015a. The geographical gradient of pine log decomposition in Japan. For Ecol Manage 349:29-35.

Fukasawa Y., 2015b. Basidiomycetous ectomycorrhizal fungal communities of current-year Pinus densiflora seedlings that regenerated on decayed logs and on the forest floor soil. J Integr Field Sci 12:19-30.

Goto Y., Kominami Y., Miyama T., Tamai K., Kanazawa K., 2003. Aboveground biomass and net primary production of a broad-leaved secondary forest in the southern part of Kyoto prefecture., central Japan. Bull FFPRI 2:115-147.

Harmon M.E., Franklin J.F., 1989. Tree seedling on logs in Picea-Tsuga forests of Oregon and Washington. Ecology $70: 48-59$. DOI: $10.2307 / 1938411$ 
Harmon M.E., Franklin J.F., Swanson F.J., Sollins P., Gregory S.V., Lattin J.D., Anderson N.H., Cline S.P., Aumen N.G., Sedell J.R., Lienkaemper G.W., Cromack K., Cummins K.W., 1986. Ecology of coarse woody debris in temperate ecosystems. Adv Ecol Res 15:133302. DOI: 10.1016/S0065-2504(08)60121-X

Heilmann-Clausen J., Aude E., van Dort K., Christensen M., Piltaver A., Veerkamp M., Walleyn R., Siller I., Standovár T., Òdor P., 2014. Communities of wood-inhabiting bryophytes and fungi on dead beech logs in Europe - reflecting substrate quality or shaped by climate and forest conditions? J Biogeo 41:2269-2282. DOI: $10.1111 /$ jbi. 12388

Hori Y., Tsuge H., 1993. Photosynthesis of bract and its contribution to seed maturity in Carpinus laxiflora. Ecol Res 8:81-83. DOI: 10.1007/BF02348610

Ishihara M.I., Suzuki S.N., Nakamura M., Enoki T., Fujiwara A., Hiura T., Homma K., Hoshino D., Hoshizaki K., Ida H., Ishida K., Itoh A., Kaneko T., Kubota K., Kuraji K., Kuramoto S., Makita A., Masaki T., Namikawa K., Niiyama K., Noguchi M., Nomiya H., Ohkubo T., Saito S., Sakai T., Sakimoto M., Sakio H., Shibano H., Sugita H., Suzuki M., Takashima A., Tanaka N., Tashiro N., Tokuchi N., Yoshida T., Yoshida Y., 2011. Forest stand structure., composition., and dynamics in 34 sites over Japan. Ecol Res Data Paper. 26:1007-1008.

Kanno H., Seiwa K., 2004. Sexual vs. vegetative reproduction in relation to forest dynamics in the understorey shrub, Hydrangea paniculata Saxifragaceae. Plant Ecol 170:43-53. DOI: 10.1023/B:VE GE.0000019027.88318.54

Kato J., Hayashi I., 2006. Quantitative analysis of a stand of Pinus densiflora undergoing succession to Quercus mongolica ssp. crispura: I. A 31-year record of growth and population dynamics of the canopy trees. Ecol Res 21:503-509. DOI: 10.1007/s11284-005-0145-7

Kobayashi M., Kamitani T., 2000. Effects of surface disturbance and light level on seedling emergence in a Japanese secondary deciduous forest. J Veg Sci 11:93-100.

DOI: $10.2307 / 3236780$

Kominami Y., Jomura M., Ataka M., Tamai K., Miyama T., Dannoura M., Makita N., Yoshimura K., 2012. Heterotrophic respiration causes seasonal hysteresis in soil respiration in a warm-temperate forest. J For Res 17:296-304. DOI: 10.1007/s10310-011-0315-0

Lonsdale D., Pautasso M., Holdenrieder O., 2008. Wood-decaying fungi in the forest: conservation needs and management options. Eur J Forest Res 127:1-22. DOI: $10.1007 / \mathrm{s} 10342-007-0182-6$

Lusk D.H., 1995. Seed size, establishment sites and species coexistence in a Chilean rain forest. J Veg Sci 6:249-256. DOI: $10.2307 / 3236220$

Mallik A.U., 2003. Conifer regeneration problems in boreal and temperate forests with ericaceous understory: role of disturbance, seedbed limitation, and keystone species change. Critic Rev Plant Sci 22:341-366. DOI: 10.1080/713610860

Mori A., Mizumachi E., Osono T., Doi Y., 2004. Substrate-associated seedling recruitment and establishment of major conifer species in an old-growth subalpine forest in central Japan. For Ecol Manage 196:287-297.
Münzbergová Z., 2004. Effect of spatial scale on factors limiting species distribution in dry grassland fragments. J Ecol 92:854-867. DOI: 10.1111/j.00220477.2004.00919.x

Nakashizuka T., 1989. Role of uprooting in composition and dynamics of an old-growth forest in Japan. Ecology 70:1273-1278. DOI: $10.2307 / 1938186$

Noguchi T., Kawamura T., Itahana N., 1991. Efficiency of mating work on intraspecific crossing of clone in Japanese red pine, Pinus densiflora Sieb. et Zucc. and productivity of seedling by stored artificially pollinated seed of them. Bull For Tree Breed Inst 9:47-81.

Ooya K., 2000. Comparison of amount and germination ratio of the seeds obtained from artificial pollination between the environments inside and outside of the greenhouse. Bull For Tree Breed Inst 17:79-85.

Osada N., 2005. Influence of between-year variation in the density of Rhus trichocarpa fruits on the removal of fruit by birds. Plant Ecol 176:195-202. DOI: 10.1007/ s11258-004-0068-3

Otani T., 2002. Seed dispersal by Japanese marten Martes melampus in the subalpine shrubland of northern Japan. Ecol Res 17:29-38. DOI: 10.1046/j.14401703.2002.00460.x

Pyle C., Brown M.M., 1999. Heterogeneity of wood decay classes within hardwood logs. For Ecol Manage 114:253-259.

$\mathrm{R}$ development core team, 2014. R: a language and environment for statistical computing $\mathrm{R}$ Foundation for Statistical Computing. Vienna, Austria.

Sakai A., Sato S., Sakai T., Kuramoto S., Tabuchi R., 2005. A soil seed bank in a mature conifer plantation and establishment of seedlings after clear-cutting in southwest Japan. J For Res 10:295-304. DOI: 10.1007/s10310004-0138-3

Sanchez E., Gallery R., Dalling J.W., 2009. Importance of nurse $\operatorname{logs}$ as a substrate for the regeneration of pioneer tree species on Barro Colorado Island, Panama. J Trop Ecol 25:429-437. DOI: 10.1017/S0266467409006130

Streng D.R., Glitzenstein J.S., Hercombe P.A., 1989. Woody seedling dynamics in an east Texas floodplain forest. Ecol Mono 59:177-204. DOI: 10.2307/2937285

Swenson N.G., Enquist B.J., Pither J., Kerkhoff A.J., Boyle B., Weiser M.D., Elser J.J., Fagan W.F., Forero-Monta-a J., Fyllas N., Kraft N.J.B., Lake J.K., Moles A.T., Pati-o S., Phillips O.L., Price C.A., Reich P.B., Quesada C.A., Stegen J.C., Valencia R., Wright I.J., Wright S.J., Andelman S., Jørgensen P.M., Lacher Jr T.E., Monteagudo A., Nú-ez-Vargas M.P., VasquezMartínez R., Nolting K.M., 2012. The biogeography and filtering of woody plant functional diversity in North and South America. Global Ecol Biogeogr 21:798-808. DOI: 10.1111/j.1466-8238.2011.00727.x

Takita M., Mizui N., Tarazawa K., Umeki K., 1998. Annual fluctuation of seed production in thirty-five deciduous broad-leaved tree species. Bull Hokkaido For Res Inst 35:1-11.

Xiao Z., Zhang Z., Wang Y., 2004. Dispersal and germination of big and small nuts of Quercus serrata in a subtropical broad-leaved evergreen forest. For Ecol Manage195:141-150. 